\title{
PSYCHE
}

\section{NEW GENERA AND SPECIES OF PERLIDA.}

BY NATHAN BANKS, WASHINGTON, D. C.

In going over my collection of stone-flies preliminary to a revision of the species, I found three new generic forms; one of them has just been described by Mr. Needham as Peltoperla; the two others are here described, as well as a few new species.

Perla attenuata n. sp.

Pale dull yellow; antennæ dark, paler on base; pronotum rather dull brownish; apical half of the abdomen brown; setæ brown, paler toward tip; wings hyaline, veins yellowish brown. Posterior ocelli rather closer to each other than to the eyes, and fully as far from the anterior ocellus; pronotum very broad, not much narrowed behind; anterior wings rather narrow, the discal cell is very slender and attenuate at base, the radial sector not bending out when arising from the radius as in other species, but running straight out or even curving forward a a little so that the discal cell is very narrow for a considerable distance; many median and cubital cross-veins; radial sector with four branches in one specimen, three in another, beyond the cross-vein. The male genital area is concave, and between the bases of the setæ is seen a pair of small, shining hamules, or hooks, pointing forward. 'The ventral plate, which is rather broad, has an elevated transverse shining spot in the middle, and from each side of which a furrow extends outward and upward. Expanse $47 \mathrm{~mm}$. Two specimens from Douglas Co., Kansas, June and July.

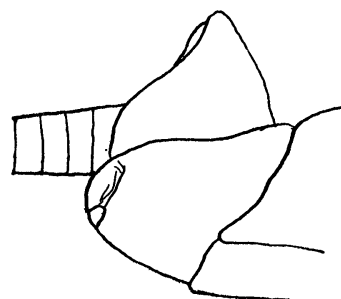

Side.

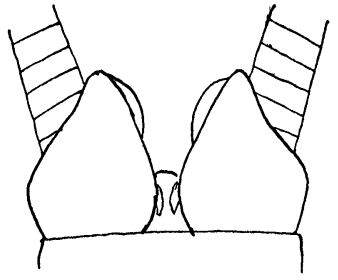

Top

Perla Kansensis $\delta$ 
Perla kansensis n. sp.

Pale yellowish, ocelli on black spots, a faint dark cloud on each side of the disk of pronotum, and the tip of the abdomen is brown; wings pale yellowish hyaline, venation wholly yellowish. Head broad, ocelli forming an equilateral triangle, and the posterior ocelli as close to eyes as to each other; pronotum narrowed behind, anterior angles acute, posterior ones rounded; legs short, the tibiæ plainly broader than usual, slightly swollen in middle. Discal cell arising beyond the second cross-vein of median area; the radial sector usually twice forked beyond the cross-vein. In the male the tip of the abdomen has a large conical tubercle above base of each seta, which viewed from below and behind is seen to be bilobed at tip. Expanse ( $ぇ$ ) $35 \mathrm{~mm}$. Douglas Co., Kansas, August. Perlinella cinctipes n. sp.

Head yellow, a broad, black intra-ocellar spot extending forward, and also laterally. Posterior ocelli as close to eyes as to each other, and fully as far from the anterior ocellus. Antennæ yellowish on basal part, beyond brown. Prothorax black, with a narrow median yellowish stripe; rest of thorax brown; legs yellowish, tarsi brown, femur I with a dorsal black streak, femora II and III with a broad black band. Abdomen brown above, pale below, but darker before the tip; setæ pale, joints tipped with brown, slender, and with a few long hairs at tip. Wings faintly brownish, venation pale, costal area yellowish, radial sector with one branch, arising farther out than in P. placida Hag. Length ro mm., expanse $18 \mathrm{~mm}$. 'Two specimens from Onaga, Kansas. Readily distinguished from $P$. placida Hag. and $P$. decipiens Walsh, by the broad black bands on femora II and III.

Atoperla n. gen.

Caudal setæ present, slender, with elongate joints, each tipped by a whorl of long hairs; with two ocelli, nearly as far apart as from the eyes; a folded anal space to hind wings; radial sector with but one branch beyond cross-vein, about three cross-veins beyond end of the subcosta. Type Perla producta Walsh. By its two ocelli it is allied to Neoperla, but differs from that genus by the nature of the setæ which are similar to those of Perlinella placıda Hag., in fact I think the structure of the setæ is of more value than the number of ocelli. Peltoperla, the other genus with two ocelli, has very short setæ; its one species, described from New York, also occurs in West Virginia.

Tænionema n. gen.

Setæ practically absent, very short. Tarsi with three sub-equal joints, the second as long as first, and the third a little longer than others. In both pairs 
of wings the subcosta is connected to the costa by three or four cross-veins, and in all wings there is a strong, oblique cross-vein beyond the end of the subcosta, which with the other veins near by tends to form an $\mathrm{X}$, not however as distinct as in Nemoura; in the fore-wings the cubitus at end of series of cross-veins curves upward toward the branch of median vein, thus forming a very large cell. Type - T. analis

This genus combines the characters of Nemoura and Taniopteryx, especially that section of Taniopteryx called Rhabdiopteryx by Klapalek. It differs from all Taniopteryx groups by the s trong cross-vein beyond the subcosta, a character of Nemoura; from Nemoura it is well separated by the long second tarsal joint, and the costal cross-veins, the latter character found also in Rhabdiopteryx. The subgenital plate of the male is much like that of the European OEniopteryx loewii Alb., but still larger.

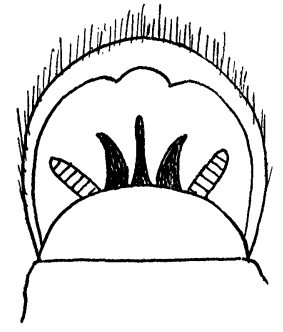

Above.

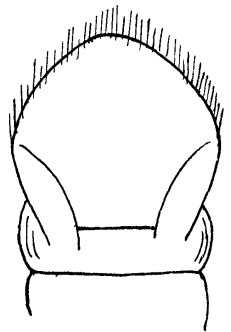

Below.

Taenionema Analis

Genitalia $\delta$

Tænionema analis n. sp.

Head shining blackish, with a pale spot in the middle, and another on clypeus; antennæ uniform dark brown; pronotum mostly blackish, but the sides rather broadly yellowish, not strongly rugose; rest of thorax black; a pale spot in middle of base of the mesothorax; abdomen black, subgenital plate yellowish; legs pale yellowish, tarsi darker; wings hyaline, venation dark. Length $\mathrm{r} 3 \mathrm{~mm}$., expense $24 \mathrm{~mm}$. From Ft. Collins, Colorado, $3^{\mathrm{I}}$ March, and Las Vegas, New Mexico (Cockerell.) 

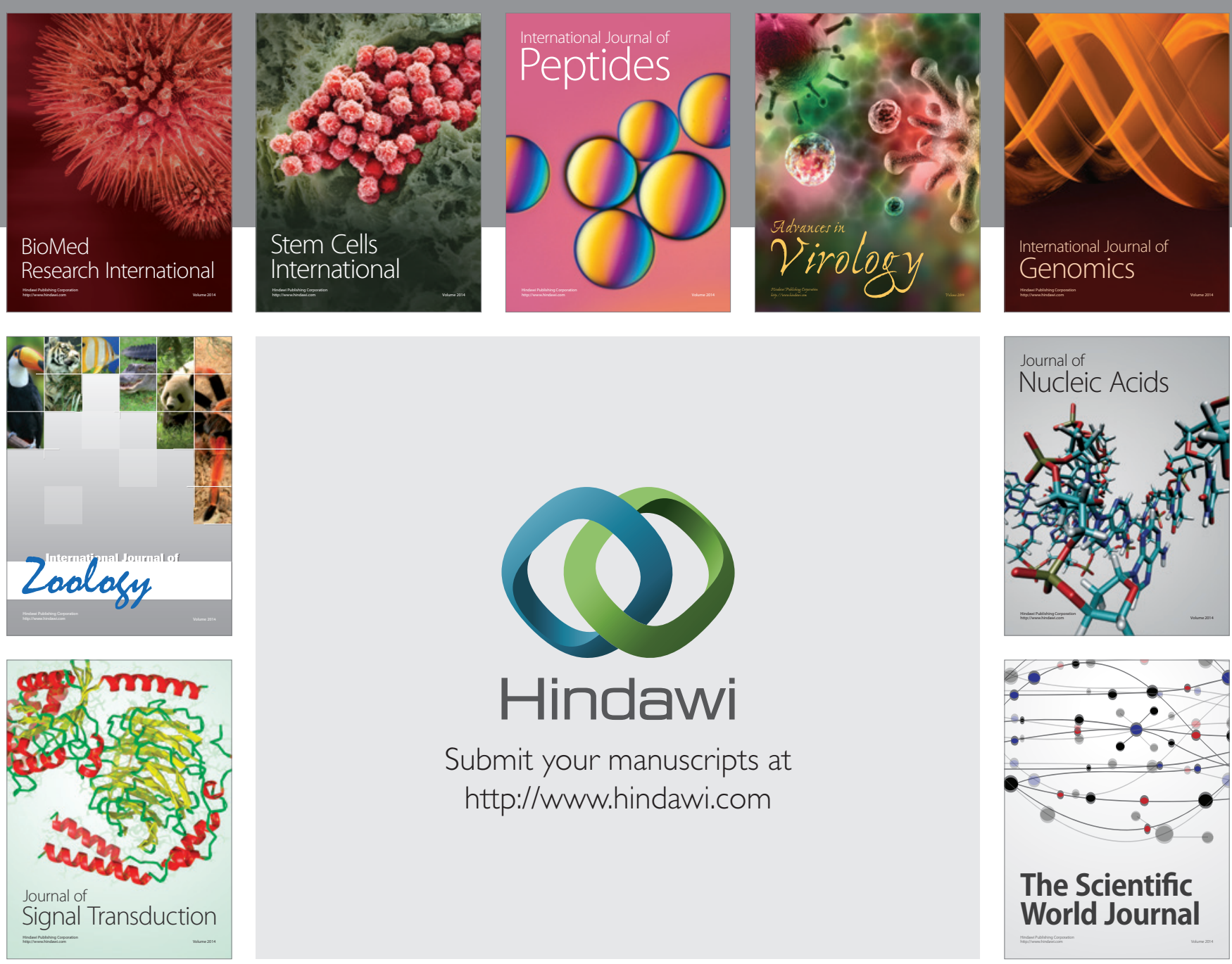

Submit your manuscripts at

http://www.hindawi.com
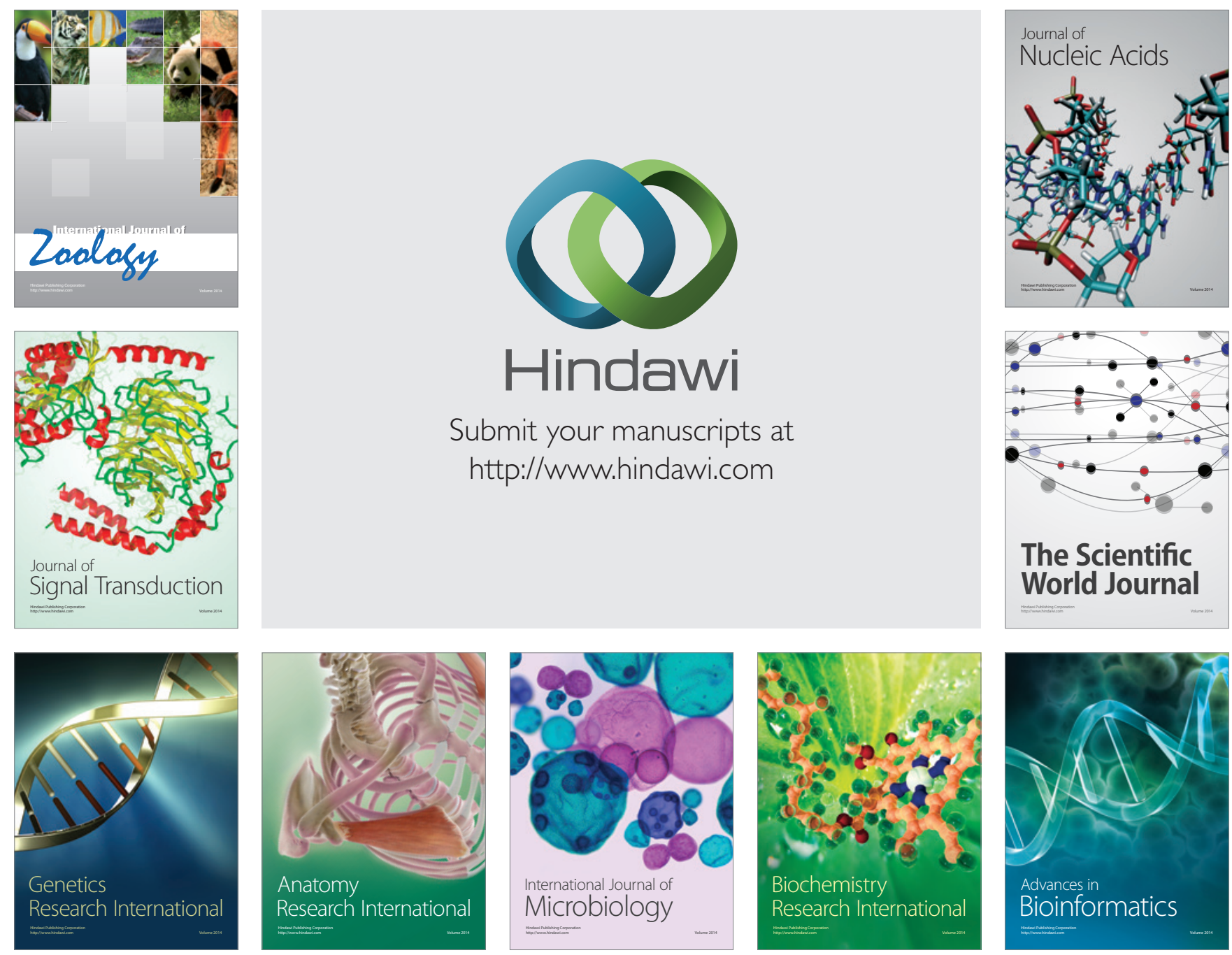

The Scientific World Journal
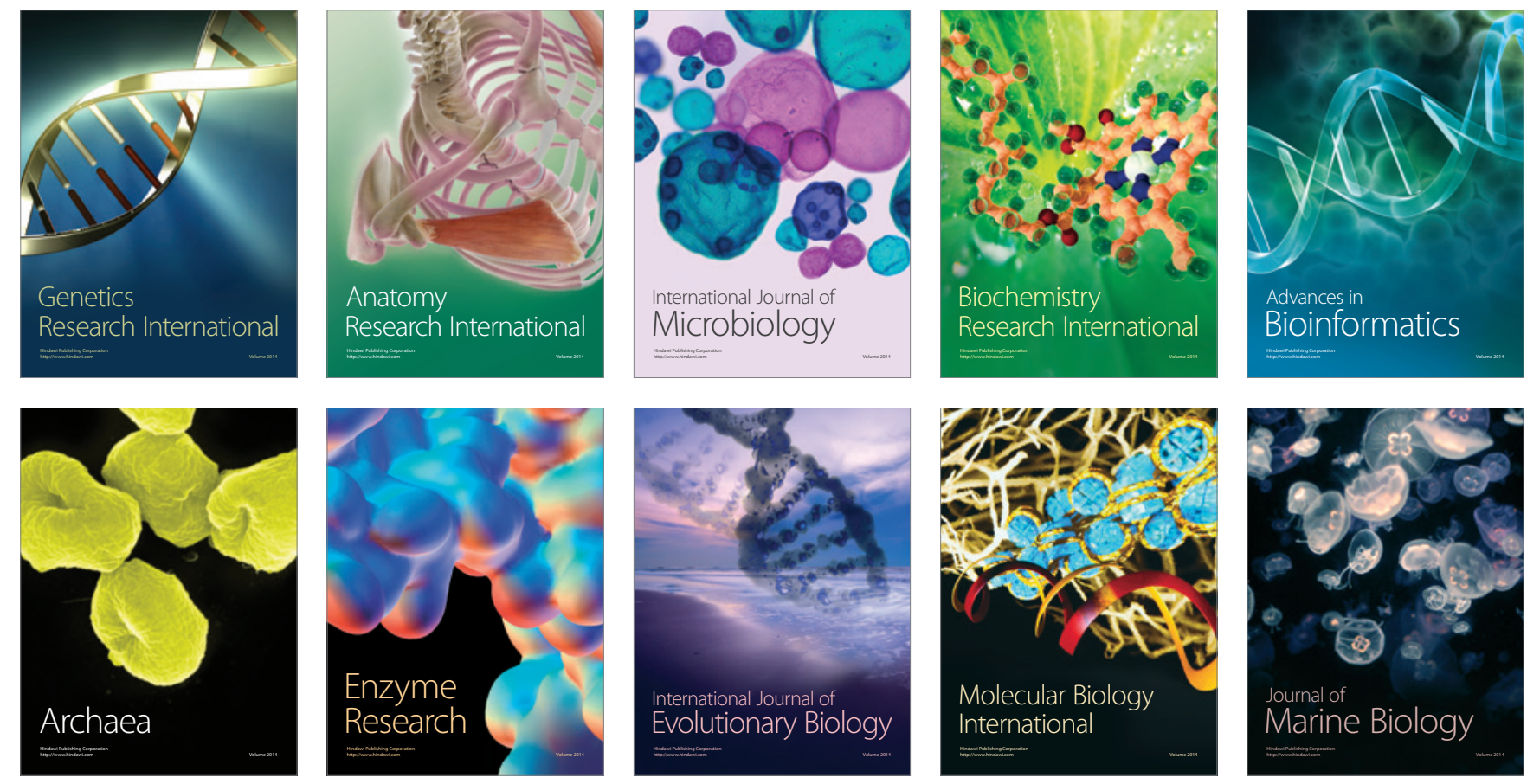